\title{
The effect of hyperbaric oxygen therapy on fracture healing in nicotinized rats
}

\author{
Abdullah Demirtaş, M.D., İbrahim Azboy, M.D., ${ }^{1}$ Mehmet Bulut, M.D., ${ }^{1}$ \\ Bekir Yavuz Uçar, M.D., ${ }^{1}$ Celil Alemdar, M.D., ${ }^{1}$ Ulaş Alabalık, M.D., ${ }^{2}$ \\ Veysi Akpolat, M.D., ${ }^{3}$ İsmail Yıldız, M.D., ${ }^{4}$ Savaş İlgezdi, M.D. ${ }^{5}$
}

\begin{abstract}
${ }^{1}$ Department of Orthopaedics and Traumatology, Dicle University Faculty of Medicine, Diyarbakir ${ }^{2}$ Department of Pathology, Dicle University Faculty of Medicine, Diyarbakir ${ }^{3}$ Department of Biophysics, Dicle University Faculty of Medicine, Diyarbakir ${ }^{4}$ Department of Biostatistics and Medical Informatics, Dicle University Faculty of Medicine, Diyarbakir ${ }^{5}$ Department of Undersea and Hyperbaric Medicine, Anadolu Hyperbaric Oxygen Centre, Istanbul
\end{abstract}

\begin{abstract}
BACKGROUND: The aim of the present study was to investigate the effect of hyperbaric oxygen therapy on fracture healing in nicotinized rats.

METHODS: Thirty-two rats were divided as follows: nicotinized group (I), hyperbaric oxygen group (2), nicotinized + hyperbaric oxygen group (3), and control group (4). For 28 days, nicotine was administered in Groups I and 3. Then, a standard shaft fracture was induced in the left femur of rats. Groups 2 and 3 underwent hyperbaric oxygen therapy for 21 days. At the end of the experiment, fracture site, left femur and whole body bone mineral content and density were measured.
\end{abstract}

RESULTS: The radiological and histopathological scores of Group I were statistically significantly lower compared to Groups 2, 3 and 4, and there was no statistically significant difference between the Groups 2, 3 and 4. In a comparison between the groups, no statistically significant difference was found in terms of bone mineral content and density values measured at the fracture site, left femur and whole body.

CONCLUSION: The negative effects of nicotine on fracture healing are eliminated with hyperbaric oxygen therapy, but hyperbaric oxygen alone does not cause significant changes in healing (radiologically and histopathologically).

Key words: Fracture healing; hyperbaric oxygen; nicotine.

\section{INTRODUCTION}

Fracture healing is a dynamic process governed by cellular and biochemical agents. Despite the investigation of many factors that may affect this process and the achieved progress on this issue, there are still problems in fracture healing. ${ }^{[1]}$

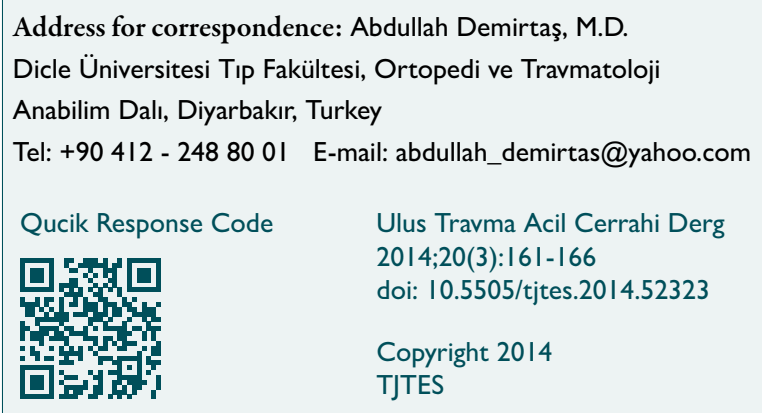

Common cigarette use in society represents a significant health problem. In the literature, it has been reported in many studies that cigarettes and their major component nicotine delay bone healing because of their negative effects on osteoblasts and tissue oxygenation. ${ }^{[2-7]}$ Hyperbaric oxygen (HBO), on the other hand, increases tolerance to ischemia by increasing tissue oxygenation ${ }^{[8-10]}$ and is used as a method of therapy in diabetic wounds, compartment syndrome, crush injuries, anaerobic infections, and irradiated wounds. ${ }^{\left[{ }^{1}\right]}$ In studies carried out recently, it has been stated that $\mathrm{HBO}$ treatment has positive effects on osteoblasts in addition to tissue oxygenation and increases bone healing. ${ }^{[2-15]}$

We postulated that the negative effects of nicotine on fracture healing could be eliminated by the positive effects of $\mathrm{HBO}$ on bone metabolism. To the best of our knowledge, there are no experimental studies evaluating the effects of nicotine and $\mathrm{HBO}$ together in a fracture healing model using 
radiological, histopathological and dual-energy X-ray absorptiometry (DXA) findings.

In this study, we investigated the effects of nicotine and $\mathrm{HBO}$ together in fracture healing in terms of radiological, histopathological and DXA findings.

\section{MATERIALS AND METHODS}

In this study, 32 male Sprague-Dawley rats (weight: 230-262 g; age: 3 months) were used. The experiments were conducted after approval was obtained from the Institutional Review Board, and animal care complied with the guidelines of the authors' institution or any national law on the care and use of laboratory animals (reference number: 201 I/62). The included rats were randomly divided into four groups $(n=8)$ : nicotinized (Group I), HBO (Group 2), nicotinized+HBO (Group 3), and control (Group 4). The rats were followed for a period of 48 hours in the lab and kept at $22^{\circ} \mathrm{C}$ during the study, with a 12-hour light and dark rhythm. For the feeding of rats, unlimited tap water and standard rodent feed were used.

Prior to the surgical procedure, for 28 days, in Groups I and 3 , nicotine (Sigma CAS No. 22083-74-5) (2 mg/kg, twice a day subcutaneously) ${ }^{[16,17]}$ and in Groups 2 and 4, saline solution (I $\mathrm{ml}$, twice a day subcutaneously) were administered.

After the surgical procedure, for 21 days, HBO (2.5 atmospheric pressure 100\% oxygen as a single session, 2 hours/ day) was applied in Groups 2 and 3 starting immediately after the surgery ${ }^{[2,14]}$ (Fig. I), whereas Groups I and 4 did not receive any therapy. At the end of the 2 Ist day, in all rats, the Kirschner wire was reached via an anterolateral incision between the femoral condyles in the left knee, under anesthesia. The Kirschner wires were removed retrogradely (in order to avoid affecting DXA measurements). After the DXA measurements, all rats were sacrificed by cervical dislocation. The left femurs of rats were disarticulated at the hip and knee joints, and the callus tissue was dissected, without damaging the soft tissues, to perform the radiological and histopathological evaluations. One rat in Group I was excluded due to infection at the fracture site.

\section{Surgical Procedure}

Preoperatively, anesthetic ketamine (Ketalar ${ }^{\circledR}$, Pfizer, Istanbul, Turkey) $50 \mathrm{mg} / \mathrm{kg}$ and xylazine (Rompun ${ }^{\circledR}$, Bayer, Istanbul, Turkey) $10 \mathrm{mg} / \mathrm{kg}$ combination was administered subcutaneously. The open osteotomy method used by Doyon et al. ${ }^{[18]}$ in their studies was applied with modification in the surgical technique. Accordingly, the left knee and femurs of the rats were shaved. The local field was cleaned with a solution of povidone iodine (Batticon ${ }^{\circledR}$, ADEKA, Istanbul, Turkey). Under sterile conditions, a $2-2.5 \mathrm{~cm}$ incision was made starting anterolateral of the left knee, extending to the lateral femur distally. Proximally, the joint was reached via the lateral parapatellar approach. The femoral condyles were ex-

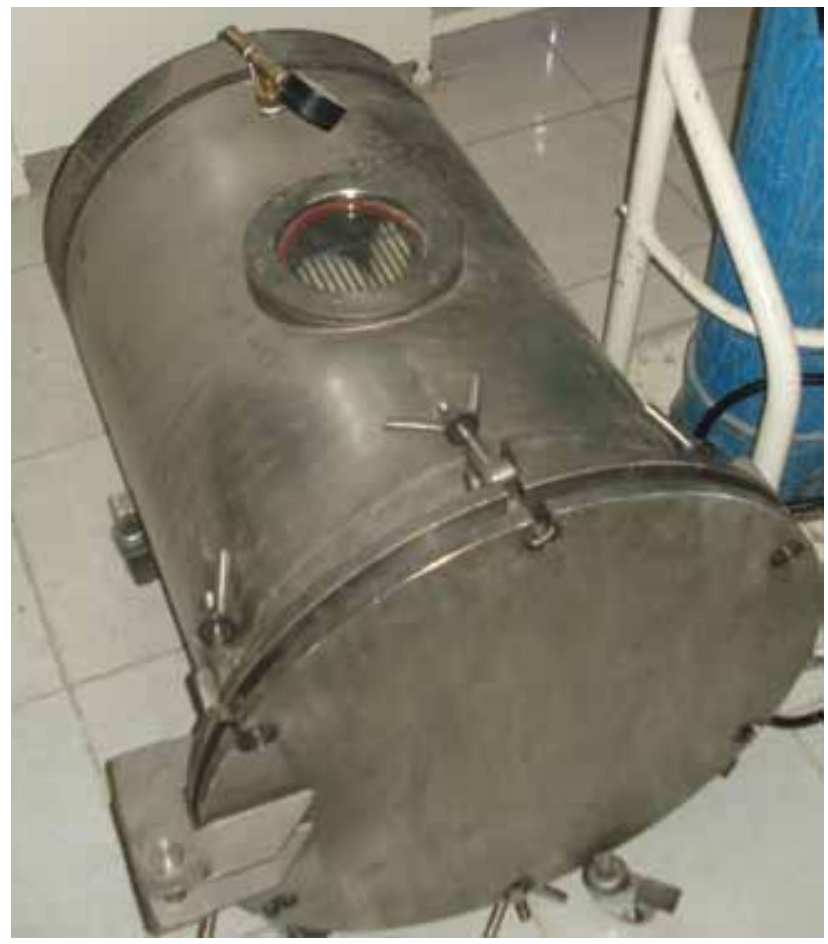

Figure 1. The images of the rats during $\mathrm{HBO}$ application.

posed by dislocating the patella medially. The distal femur was reached with blunt dissection along the vastus lateralis and hamstring muscles. The standard fracture was induced with a Gigli wire, at the middle I/3 of the femur shaft. Kirschner wire (Hippocrates ${ }^{\circledR}$, Izmir, Turkey) of I mm diameter was placed retrogradely in the intramedullary canal, towards the greater trochanter from the distal femoral condyles. After the fixation of the fracture, the patella was reduced and stabilized with absorbable sutures. Following the closure of the skin with non-absorbable sutures, the wound was cleaned with povidone iodine.

Table I. The histopathological scoring for the evaluation of fracture healing

\begin{tabular}{ll}
\hline Score & Histopathological findings \\
\hline 1 & Fibrous tissue \\
2 & Predominantly fibrous tissue with little cartilage tissue \\
3 & Equal amounts of fibrous and cartilage tissue \\
4 & Only cartilage tissue \\
5 & Predominantly cartilage tissue with little immature \\
6 & (woven) bone \\
7 & Equal amounts of cartilage and immature bone tissue \\
8 & Predominantly immature bone with little cartilage \\
9 & tissue \\
10 & Healing with immature (woven) bone \\
\hline
\end{tabular}




\section{Radiological Evaluation}

For the radiological evaluation, anteroposterior and lateral radiographs of the left femurs of the rats were taken. The healing was evaluated by an independent orthopedic surgeon, using the radiological scoring system described by Lane et al., ${ }^{[19]}$ over 4 points $(0=$ no healing, I=callus formation, $2=$ onset of bony union, 3 =beginning of disappearance of fracture line, 4=complete bony union). In bilateral group comparisons, a decrease in the score was assigned as a negative effect on fracture healing, whereas an increase was evaluated as a positive effect.

\section{Histopathological Evaluation}

For the histopathological assessment, all femurs were fixed in $10 \%$ buffered formalin solution for a period of two weeks, and then in Bouin's solution for two days. After the fixation, the femurs were decalcified in $10 \%$ acetic acid, $0.85 \% \mathrm{NaCl}$ and $10 \%$ formalin solutions. The samples were then embedded in paraffin blocks and after the 3-4 micron thick sections were taken, they were stained with hematoxylin and eosin. For the evaluation of fracture healing, the histopathological improvement scale, as defined by Huo et al., ${ }^{[20]}$ in which scoring is done over 10 points, was used (Table I). The slides were evaluated by the same pathologist to ensure standardization. In bilateral group comparisons, a decrease in the score was assigned as a negative effect on fracture healing, whereas an increase was evaluated as a positive effect.

\section{DXA Assessment}

The left femur fracture site (the fracture center plus an area of $0.3 \mathrm{~cm}$ proximally and distally), whole left femur and whole body bone mineral density (BMD) and bone mineral content (BMC) measurements of the rats were done using DXA (Hologic, Discovery QDR 4500A, WA, USA). Before each procedure, calibration of the instrument was done in accordance with the manufacturer's standard "small step phantom", including the two measurements and the recordings before and after the application of the "small animal" mode. The measurements were assessed by the same person to ensure standardization.

\section{Statistical Evaluation}

All the data were recorded and analyzed using the SPSS (Statistical Package for the Social Sciences) 18.0. The Kolmogorov-Smirnov and Shapiro-Wilk tests were performed to determine if the data were normally distributed. Nonparametric tests were performed for the parameters without a normal distribution. The Kruskal-Wallis test was used for comparison between the groups. The Mann-Whitney $U$ test was used for comparison between two groups in radiological, histopathological and DXA evaluations. The data were summarized as median (minimum-maximum). A p value $<0.05$ was considered statistically significant.
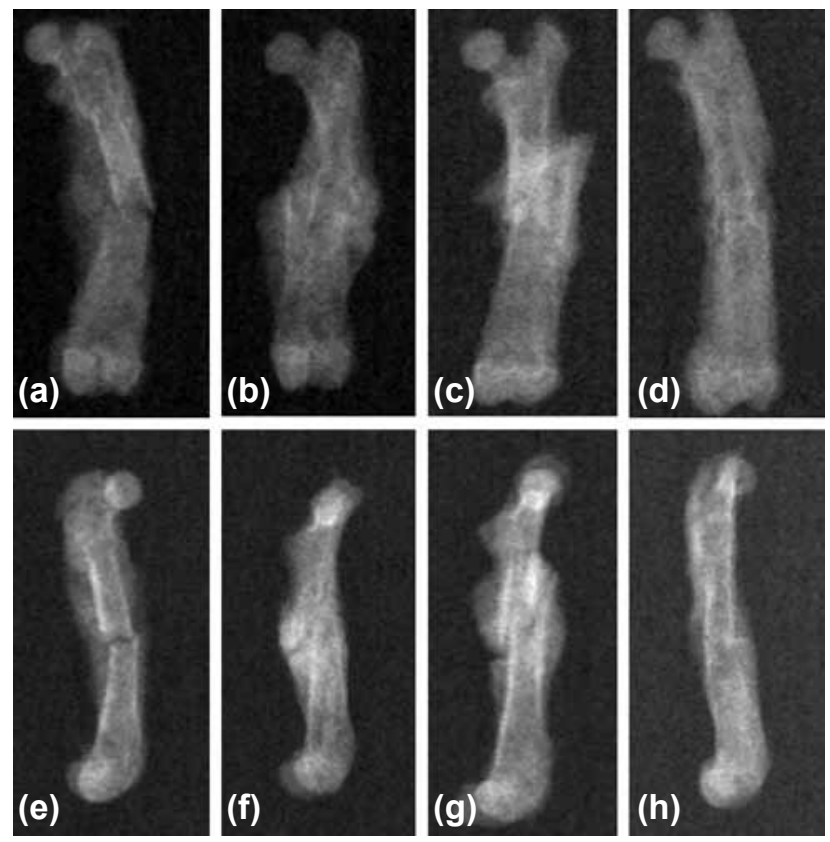

Figure 2. The anteroposterior [(a) Group 1; (b) Group 2; (c) Group 3; (d) Group 4] and the lateral [(e) Group 1; (f) Group 2; (g) Group 3; (h) Group 4] X-ray images of the samples of the groups at the end of the experiment.

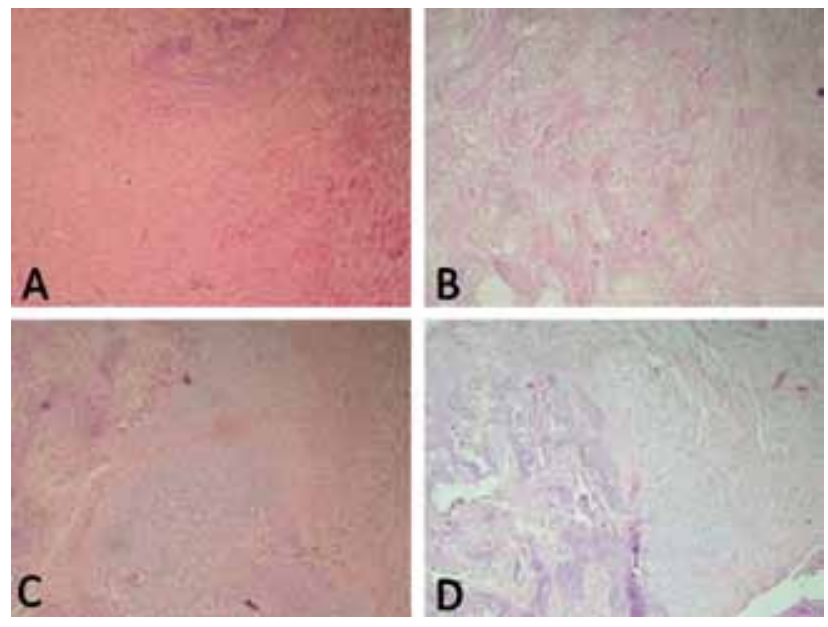

Figure 3. The histopathological images of the samples of the groups at the end of the experiment: (a) In a rat in Group 1, a field containing a small amount of cartilage, with mostly fibrous tissue [hematoxylin \& eosin (H\&E, 100x)]; (b) In a rat in Group 2, a field full of immature bone tissue (H\&E, 100x); (c) In a rat in Group 3, a field containing mostly cartilage and a small amount of immature bone tissue (H\&E, 100x); and (d) In a rat in Group 4, a field containing equal amounts of cartilage and immature bone tissue (H\&E, 100x).

\section{RESULTS}

\section{Radiological Findings}

The radiological scores for all groups are given in Table 2. The radiological score of Group I was significantly lower as compared to Groups 2, 3 and $4(p=0.009, p=0.027, p=0.016$, respectively). There was no statistically significant difference be- 


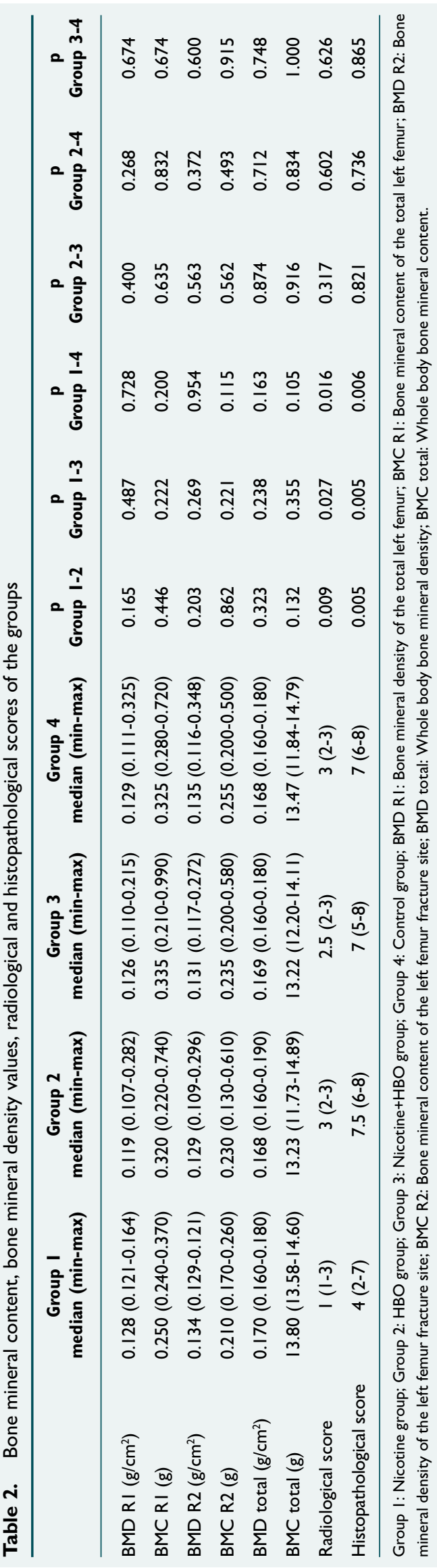

tween Groups 2, 3 and 4 in terms of radiological scores ( $p>0.05$ ) (Fig. 2).

\section{Histopathological Findings}

The histopathological scores of all tissue samples taken from all groups at the end of the 2 Ist day are given in Table 2 . The histopathological score of Group I was statistically significantly lower compared to Groups 2,3 and 4 ( $p=0.005, p=0.005, p=0.006$, respectively). There was no statistically significant difference between Groups 2, 3 and 4 in terms of histopathological scores ( $p>0.05$ ) (Fig. 3).

\section{DXA Findings}

Table 2 shows the fracture site, whole left femur and whole body BMC and BMD values measured in all groups, before the experiment was terminated, at the end of the $2 \mathrm{I}$ st day. There was no statistically significant difference between groups in terms of BMC and BMD values $(p>0.05)$.

\section{DISCUSSION}

Many factors having an effect on fracture healing have been analyzed, and nicotine is among the most well known. In many studies in the literature, nicotine has been reported to reduce BMD and to delay healing due to its negative effects on bone metabolism. ${ }^{[2-7,21,22]}$

Nicotine delays fracture healing through different mechanisms of action. In a rabbit model of mandibular lengthening, Zheng et al. ${ }^{[3]}$ studied the effects of nicotine on bone healing, and reported that nicotine reduces bone formation by their inhibitory effect on osteoblasts. In the same study, they also demonstrated that nicotine reduces blood flow due to the lack of compensation for vasoconstriction in the distraction regenerate and decreases bone formation due to the decreased oxygen tension. Theiss et al. ${ }^{[4]}$ reported that nicotine reduces the expression of genes related to cytokines, which affect osteoblast differentiation and neoangiogenesis. Chen et al. ${ }^{[2]}$ reported that nicotine delays fracture healing by inhibiting the secretion of tumor necrosis factor (TNF)- $\alpha$ through the activation of the cholinergic anti-inflammatory pathway.

In our study, a fixed dose of subcutaneous nicotine was given for the nicotinization of the rats. The exposure of the rats to nicotine was ended preoperatively because we believe that patients subject to a fracture would stop smoking for at least the duration of healing. However, we believe that the negative effects of smoking would not disappear immediately after cessation of smoking. In our study, a significant negative effect on fracture healing was observed in the nicotinized compared with the control group, in terms of the radiological and histopathological findings ( $p=0.016, p=0.006$, respectively). This demonstrates that the negative effects of nicotine continue despite the preoperative cessation of nicotine administration.

The HBO therapy is a method of $100 \%$ oxygen inhalation, in a closed pressure chamber, at high pressure of more than I atmosphere. In many studies, HBO therapy has been reported to have positive effects on bone healing. ${ }^{[12-15]} \mathrm{Wu}^{[12]}$ and $\mathrm{Hsieh}$ et al., ${ }^{[13]}$ in their studies investigating the effectiveness of $\mathrm{HBO}$ on human osteoblasts in vitro, reported that $\mathrm{HBO}$ increases the proliferation and differentiation of osteoblasts. Muhonen et al. ${ }^{[15]}$ reported in a mandibular distraction osteogenesis model they created in rabbits, that preoperative HBO application increases the cor- 
rupted osteoblastic activity in bones that previously received radiation, but it could not be taken to the level of the control group not receiving radiation. In the same study, it was stated that $\mathrm{HBO}$ has apparent effects on neovascularization.

In the literature, there are studies conducted with different agents, which eliminate the negative effects of nicotine on wound healing. ${ }^{[23]}$ As far as we know, only two studies have been conducted on the effectiveness of $\mathrm{HBO}$ to resolve the negative effects of nicotine on bone healing. In a model of tibial lengthening in rabbits, using BMD measurements and biomechanical testing, Ueng et al. ${ }^{[2]}$ reported that inhalation of cigarettes delays bone healing, and HBO therapy accelerates the healing by reducing the effect of the cigarettes. In their study in rabbits, Yen et al. ${ }^{[24]}$ reported that by inhalation of cigarettes, bone healing was delayed as a result of impaired function of the tibial vascular endothelial cells and decreased blood flow. The same study also emphasized that HBO reduces the deleterious effects of smoking.

In our study, there was a statistically significant difference in radiological and histopathological scores in the nicotinized $+\mathrm{HBO}$ group compared to the nicotinized group, whereas no statistically significant difference was found between the HBO, nicotinized $+\mathrm{HBO}$ and control groups (Table 2). This suggested that the negative effects of nicotine on fracture healing are eliminated with HBO therapy, but HBO alone did not cause significant changes in healing radiologically or histopathologically. This condition may have been caused by the fact that $\mathrm{HBO}$ can manifest its positive effects on fracture healing more apparently in the presence of the negative effects of nicotine (probably due to the interaction of reverse mechanisms), while its positive effects are not sufficiently manifested in the absence of nicotine (probably due to the other more effective factors on the process). In some studies in the literature, it has been shown that positive effects of $\mathrm{HBO}$ treatment on bone metabolism occur in longer terms than the length of our follow-up. Kürklü et al. ${ }^{[25]}$ reported in a nonunion model they created in rabbit tibia that applying HBO therapy 2 hours per day over a 20-day period under 2.5 atmospheric pressure did not affect healing on the 30th day radiologically or scintigraphically, while healing increased to a significant level on the 90th day. Chen et al. ${ }^{[26]}$ reported in a lumbar intertransverse fusion model in rabbits that application of HBO therapy 2 hours per day under 2.5 atmospheric pressure had accelerated healing significantly in the 4th and 8th weeks in terms of radiologic, manual assessment and torsional overload findings. Eralp et al. ${ }^{[27]}$ reported in a bone defect model they created in rat tibia that 6-week HBO application increased the healing significantly radiologically and histologically. In light of the literature, in a longer-term follow-up model of femur fracture, we think that $\mathrm{HBO}$ can have an effect on fracture healing.

In our study, in the comparison of groups, no statistically significant difference was found in terms of the BMC and BMD values measured in the left femur fracture site, total left femur and whole body $(p>0.05)$. Although these findings support the radiological and histopathological aspects in the $\mathrm{HBO}$, nicotinized $+\mathrm{HBO}$ and the control groups, they do not support the findings in the nicotinized group. This condition may be due to the fact that DXA findings related to nicotine are revealed later than radiologic and histopathological findings in bone healing. Different results have been reported in studies in the literature concerning the timing of DXA findings related to nicotine. Ueng et al. ${ }^{[2]}$ reported that nicotine begins to change BMD values after 3 weeks and reduces progressively in the 4th, 5th and 6th weeks in proportion to application time. Fung et al. ${ }^{[28]}$ reported that a 2-month period of nicotine application does not change BMC and BMD values. Gao et al. ${ }^{[29]}$ reported that 2- or 3- month periods of nicotine application did not change BMD values, but a 4-month period of application reduced BMD values. The controversial results were likely due to the variable dosages and methods of nicotine administration and the different healing models used to study the influence of nicotine. ${ }^{[3]}$ We think that, in the case of a longer follow-up, there would be a significant correlation between the DXA findings and the radiological and histopathological findings in all groups.

The limitations of our study are the short follow-up and the lack of different dosages and durations of the nicotinization procedure and $\mathrm{HBO}$ therapy. New studies evaluating the association between different types of nicotinization procedures and HBO therapy might be performed.

In conclusion, in the short-term follow-up, the negative effects of nicotine on fracture healing were relieved with $\mathrm{HBO}$ therapy; however, $\mathrm{HBO}$ alone did not cause significant changes in healing, radiologically or histopathologically. We suggest that patients who undergo surgery for fracture should cease smoking and receive $\mathrm{HBO}$ therapy.

\section{Conflict of interest: None declared.}

\section{REFERENCES}

1. Buckwalter JA, Einhorn TA, Marsh JL. Bone and joint healing. In: Rockwood CA, Green DP, Bucholz RW, Heckman JD, editors. Rockwood and Green's Fractures in Adults. Vol 1. 5th ed. Philadelphia: Lippincott Williams and Wilkins; 2001.p. 245-71.

2. Ueng SW, Lee SS, Lin SS, Wang CR, Liu SJ, Tai CL, et al. Hyperbaric oxygen therapy mitigates the adverse effect of cigarette smoking on the bone healing of tibial lengthening: an experimental study on rabbits. J Trauma 1999;47:752-9.

3. Zheng LW, Ma L, Cheung LK. Changes in blood perfusion and bone healing induced by nicotine during distraction osteogenesis. Bone 2008;43:355-61.

4. Theiss SM, Boden SD, Hair G, Titus L, Morone MA, Ugbo J. The effect of nicotine on gene expression during spine fusion. Spine (Phila $\mathrm{Pa} 1976$ ) 2000;25:2588-94.

5. Walker LM, Preston MR, Magnay JL, Thomas PB, El Haj AJ. Nicotinic regulation of $c$-fos and osteopontin expression in human-derived osteoblast-like cells and human trabecular bone organ culture. Bone 2001;28:603-8.

6. Yuhara S, Kasagi S, Inoue A, Otsuka E, Hirose S, Hagiwara H. Effects of 
nicotine on cultured cells suggest that it can influence the formation and resorption of bone. Eur J Pharmacol 1999;383:387-93.

7. Kucukdeveci O, Sarisozen B, Atici T, Ozcan R. The effect of nicotine on distraction osteogenesis: an experimental study on rabbits. J Trauma 2009;67:1376-83.

8. Zhang Q, Chang Q, Cox RA, Gong X, Gould LJ. Hyperbaric oxygen attenuates apoptosis and decreases inflammation in an ischemic wound model. J Invest Dermatol 2008;128:2102-12.

9. Richards L, Lineaweaver WC, Stile F, Zhang J, Zhang F. Effect of hyperbaric oxygen therapy on the tubed pedicle flap survival in a rat model. Ann Plast Surg 2003;50:51-6.

10. Hong JP, Kwon H, Chung YK, Jung SH. The effect of hyperbaric oxygen on ischemia-reperfusion injury: an experimental study in a rat musculocutaneous flap. Ann Plast Surg 2003;51:478-87.

11. Gill AL, Bell CN. Hyperbaric oxygen: its uses, mechanisms of action and outcomes. QJM 2004;97:385-95.

12. Wu D, Malda J, Crawford R, Xiao Y. Effects of hyperbaric oxygen on proliferation and differentiation of osteoblasts from human alveolar bone. Connect Tissue Res 2007;48:206-13.

13. Hsieh CP, Chiou YL, Lin CY. Hyperbaric oxygen-stimulated proliferation and growth of osteoblasts may be mediated through the FGF-2/ MEK/ERK 1/2/NF-KB and PKC/JNK pathways. Connect Tissue Res 2010;51:497-509.

14. Ueng SW, Lee SS, Lin SS, Wang CR, Liu SJ, Yang HF, et al. Bone healing of tibial lengthening is enhanced by hyperbaric oxygen therapy: a study of bone mineral density and torsional strength on rabbits. J Trauma 1998;44:676-81.

15. Muhonen A, Haaparanta M, Grönroos T, Bergman J, Knuuti J, Hinkka $\mathrm{S}$, et al. Osteoblastic activity and neoangiogenesis in distracted bone of irradiated rabbit mandible with or without hyperbaric oxygen treatment. Int J Oral Maxillofac Surg 2004;33:173-8.

16. Eskitascioglu T, Gunay GK. The effects of topical prostacyclin and prostaglandin E1 on flap survival after nicotine application in rats. Ann Plast Surg 2005;55:202-6.

17. Selçuk CT, Kuvat SV, Bozkurt M, Yaşar Z, Gülsün N, Ilgezdi S, et al. The effect of hyperbaric oxygen therapy on the survival of random pattern skin flaps in nicotine-treated rats. J Plast Reconstr Aesthet Surg
2012;65:489-93.

18. Doyon AR, Ferries IK, Li J. Glucocorticoid attenuates the anabolic effects of parathyroid hormone on fracture repair. Calcif Tissue Int 2010;87:68-76.

19. Lane JM, Sandhu HS. Current approaches to experimental bone grafting. Orthop Clin North Am 1987;18:213-25.

20. Huo MH, Troiano NW, Pelker RR, Gundberg CM, Friedlaender GE. The influence of ibuprofen on fracture repair: biomechanical, biochemical, histologic, and histomorphometric parameters in rats. J Orthop Res 1991;9:383-90.

21. Chen Y, Guo Q, Pan X, Qin L, Zhang P. Smoking and impaired bone healing: will activation of cholinergic anti-inflammatory pathway be the bridge? Int Orthop 2011;35:1267-70.

22. Kyrö A, Usenius JP, Aarnio M, Kunnamo I, Avikainen V. Are smokers a risk group for delayed healing of tibial shaft fractures? Ann Chir Gynaecol 1993;82:254-62.

23. Baykan H, Günay GK, Ozyazgan I, Soyuer I. The effect of angiotensin (1-7) on survival of random pattern skin flaps with nicotine-induced ischemia in rats. Ann Plast Surg 2012;68:88-93.

24. Yen CY, Tu YK, Ma CH, Yeh JH, Kao FC, Yu SW, et al. Measurement of tibial endothelial cell function after cigarette smoking, cessation of smoking and hyperbaric oxygen therapy. Injury 2008;39 Suppl 4:40-6.

25. Kürklü M, Yurttaş Y, Köse O, Demiralp B, Yüksel HY, Kömürcü M. Adjunctive hyperbaric oxygen therapy in the treatment of atrophic tibial nonunion with Ilizarov external fixator: a radiographic and scintigraphic study in rabbits. Acta Orthop Traumatol Turc 2012;46:126-31.

26. Chen WJ, Lai PL, Chang CH, Lee MS, Chen CH, Tai CL. The effect of hyperbaric oxygen therapy on spinal fusion: using the model of posterolateral intertransverse fusion in rabbits. J Trauma 2002;52:333-8.

27. Eralp L, Kocaoğlu M, Ozkan K, Türker M. A comparison of two osteotomy techniques for tibial lengthening. Arch Orthop Trauma Surg 2004;124:298-300.

28. Fung YK, Mendlik MG, Haven MC, Akhter MP, Kimmel DB. Shortterm effects of nicotine on bone and calciotropic hormones in adult female rats. Pharmacol Toxicol 1998;82:243-9.

29. Gao SG, Li KH, Xu M, Jiang W, Shen H, Luo W, et al. Bone turnover in passive smoking female rat: relationships to change in bone mineral density. BMC Musculoskelet Disord 2011;12:131.

\title{
DENEYSEL ÇALIŞMA - ÖZET
}

\section{Nikotinize sıçanlarda hiperbarik oksijen tedavisinin kırık iyileşmesi üzerine etkisi}

\section{Dr. Abdullah Demirtaş, ${ }^{1}$ Dr. İbrahim Azboy, ${ }^{1}$ Dr. Mehmet Bulut, ${ }^{1}$ Dr. Bekir Yavuz Uçar, Dr. Celil Alemdar, ${ }^{1}$ Dr. Ulaş Alabalık, ${ }^{2}$ Dr. Veysi Akpolat, ${ }^{3}$ Dr. İsmail Yıldız, ${ }^{4}$ Dr. Savaş İlgezdi ${ }^{5}$}

\author{
1Dicle Üniversitesi Tıp Fakültesi, Ortopedi ve Travmatoloji Anabilim Dalı, Diyarbakır \\ ${ }^{2}$ Dicle Üniversitesi Tıp Fakültesi, Patoloji Anabilim Dalı, Diyarbakır \\ ${ }^{3}$ Dicle Üniversitesi Tıp Fakültesi, Biyofizik Anabilim Dalı, Diyarbakır \\ ${ }^{4}$ Dicle Üniversitesi Tıp Fakültesi, Tıbbi Biyoistatistik Anabilim Dalı, Diyarbakır \\ ${ }^{5}$ Anadolu Hiberbarik Oksijen Merkezi, Sualtı Hekimliği ve Hiperbarik Tıp Anabilim Dalı, İstanbul
}

AMAÇ: Bu çalışmanın amacı, nikotinize sıçanlarda hiperbarik oksijen tedavisinin kırık iyileşmesi üzerine etkisini incelemektir.

GEREÇ VE YÖNTEM: Otuz iki adet sıçan dört gruba ayrıldı: nikotinize grup (I), hiperbarik oksijen grubu (2), nikotinize + hiperbarik oksijen grubu (3) ve kontrol grubu (4). Yirmi sekiz gün boyunca grup I ve grup 3'e nikotin uygulandı. Daha sonra, sıçanların sol femurlarında standart cisim kırı̆ı oluşturuldu. Yirmi bir gün boyunca grup 2 ve grup 3'e hiperbarik oksijen tedavisi uygulandı. Deneyin sonunda kırık alanı, sol femur ve tüm vücut kemik mineral içeriği ve dansitesi ölçüldü.

BULGULAR: Radyolojik ve histopatolojik skorlar grup I'de, grup 2, 3 ve 4'e göre anlamlı düzeyde düşük bulundu. Grup 2, 3 ve 4 arasında radyolojik ve histopatolojik skorlar açııından istatistiksel olarak anlamlı fark saptanmadı. Gruplar arası karşılaştırmada kırık alanı, total sol femur ve tüm vücutta ölçülen kemik mineral içeriği ve dansitesi değerleri bakımından istatistiksel olarak anlamlı fark bulunmadı.

TARTIŞMA: Nikotinin kırık iyileşmesi üzerindeki olumsuz etkileri hiperbarik oksijen tedavisi ile giderilmekte, ancak hiperbarik oksijen tek başına radyolojik ve histopatolojik olarak iyileşme üzerinde anlamlı değişikliğe sebep olmamaktadır.

Anahtar sözcükler: Hiperbarik oksijen; kırık iyileşmesi; nikotin. 